\title{
Cashmere Quality of Iranian Goat Breeds
}

\author{
H. R. Ansari-Renani \\ Animal Science Research Institute \\ P. O. Box. 31585-1483, Karaj I. R. Iran \\ (Received 29-06-2012; Reviewed 28-10-2012; Accepted 22-11-2012)
}

\begin{abstract}
This paper assesses the cashmere quality in different Iranian cashmere goat breeds to determine the scope for improvement of fiber quality. In April 2009 midside cashmere samples were taken from a total of 168 male and female cashmere goats of 1, 2,3, and 4 yr of age. The goats were randomly chosen from Raeini, Birjandi, and Nadoushan breeds respectively from Kerman, South Khorasan, and Yazd provinces. Cashmere yield (CY) was determined from the percentage of weight of dehaired cashmere to weight of shorn fibre. Cashmere fiber diameter was analyzed using a projection microscope instrument. A general linear model including sex and age as fixed effects and breed as random effect was used to analyze the data and measure the relationships between different cashmere characteristics and fleece attributes. The overall means \pm standard deviations were for cashmere yield (CY) $51.4 \% \pm 1.5 \%$, mean fiber diameter (MFD) $18.7 \pm 0.2 \mu \mathrm{m}$, coefficient of variation of fiber diameter (CVFD) $19.1 \% \pm 0.3 \%$ and staple length (SL) $42.8 \pm 1.6 \mathrm{~mm}$. One year old goats had finer cashmere than older goats. CVFD were higher in males and CY and SL were higher in young animals. Iranian cashmere goat breeds have an excellent SL but are relatively coarse. Given the differences between goats there seems to be substantial scope to improve the commercial value of cashmere.
\end{abstract}

Key words: cashmere, goats, fiber diameter, staple length

\section{ABSTRAK}

Penelitian ini mengkaji kualitas kasmir pada beberapa bangsa kambing kasmir Iran untuk menentukan ruang lingkup bagi perbaikan kualitas serat. Sampel kasmir dari bagian sisi tengah yang diambil dari 168 ekor kambing jantan dan betina berumur 1, 2, 3, dan 4 tahun pada April 2009. Kambing dipilih secara acak dari bangsa Raeini, Birjandi, dan Nadoushan yang secara berurutan berasal dari Propinsi Kerman, South Khorasan, dan Yazd. Produksi kasmir (CY) ditentukan dari persen bobot kasmir tanpa bulu terhadap serat yang dicukur. Diameter serat kasmir dianalisa menggunakan peralatan mikroskop proyeksi. Model persamaan linier, yang meliputi jenis kelamin dan umur sebagai peubah tetap dan bangsa sebagai peubah acak, digunakan untuk menganalisis data dan mengukur hubungan antara karakteristik kasmir yang berbeda dengan atribut bulu domba. Rataan dan standar deviasi untuk produksi kasmir (CY) adalah $51.4 \% \pm 1.5 \%$, dimater serat (MFD) $18.7 \pm 0.2 \mu \mathrm{m}$, koefisien variasi dari diameter serat (CVFD) $19.1 \% \pm 0.3 \%$, dan panjang serabut (SL) $42.8 \pm 1.6 \mathrm{~mm}$. Kambing berumur satu tahun memiliki kasmir yang lebih baik dibanding dengan kambing dengan umur lebih tua. Nilai CVFD pada kambing jantan lebih tinggi dibandingkan dengan betina, dan nilai CY dan SL lebih tinggi pada kambing muda. Bangsa kambing kasmir Iran memiliki nilai SL yang sangat baik, tetapi relatif kasar. Adanya perbedaan yang terdapat di antara kambing, menjadi lingkup yang penting untuk meningkatkan nilai komersial kasmir.

Kata kunci: kasmir, kambing, diameter serat, panjang serabut

\section{INTRODUCTION}

The fleece of cashmere goats grows from specialized follicles in the skin. While primary follicles bear

*Corresponding author:

E-mail: ansarirenani@yahoo.com guard hair which are characteristically medulated and coarse $(>30 \mu \mathrm{m})$ and provide a mechanical protection, secondary follicles are more numerous than primary follicles and produce non-medulated fine cashmere fibre $(<24 \mu \mathrm{m})$ which provide thermal protection (Nixon, et al., 1991; Ansari-Renani, et al. 2007). Cashmere is the fine, undercoat fibre (down) produced by cashmere goats in some of the most arid parts of Central Asia, including 
China, Mongolia, Iran and Afghanistan. Cashmere quality is primarily determined by diameter, length and the colour (Schneider, 2011) however in the field situation, traders use the degree of cashmere fiber crimping (waviness) to estimate the mean fiber diameter.

Cashmere is a luxury fibre regarded as one of the softest and warmest animal fibres principally used for clothing. Annual production of cashmere is $<0.01 \%$ of the world textile market and its contribution to the annual global fiber tonnage is negligible. Iran together with Afghanistan is the third largest producer and exporter of cashmere in the world, after China and Mongolia (FAO, 2011).

The goat population in Iran is 25 million (FAO, 2011 ), of this population $20 \%$ is cashmere producing goats of Raeini, Birjandi, and Nadushan breeds located mainly in the eastern provinces of Kerman, South Khorasan, and Yazd respectively. Forty percent of the population of goats is kept by nomads (Ashayer) in a habitat of about $59 \%$ of the total area of the country (Ministry of Agriculture, 2004).

More than $50 \%$ of the Iranian cashmere is produced by Raeini goats kept by nomads. Nomad livelihood is based on keeping goats mainly for meat, cashmere, milk, skin production and to a lesser degree for ceremonial and socio-economic purposes. There is however, a potential for obtaining additional income or adding value by making better use of cashmere.

Iranian cashmere is generally designated as 2-3 $\mu \mathrm{m}$ coarser than Chinese and Mongolian cashmere (Petrie, 1995) and is therefore cheaper (Schneider, 2011). McGregor (2007) tested cashmere from different origins of the world, including 18 samples from Iran and found that the Iranian cashmere was coarser, longer and crimpier than cashmere from China and Afghanistan. Beyond that, little additional information on Iranian cashmere characteristics is available. This paper studies cashmere quality and its variation of different goat breeds in the main cashmere producing region in Iran in order to determine the scope for improvement, in particular of fineness which would increase the market price and thereby the income of the cashmere producers in general and nomads in particular.

\section{MATERIALS AND METHODS}

\section{Study Area and Goat Management Systems}

Raeini breed in Kerman province is a cashmere producing goat with an average live weight of $35 \mathrm{~kg}$ for males and $30 \mathrm{~kg}$ for females which produce mainly white cashmere. Kerman province is a highland region with $<250 \mathrm{~mm}$ annual rain and $85 \%$ of the nutrition of goats is based on range and $15 \%$ on forage and post harvest cereals produced in farms for fall and winter feeding. Summer is hot (up to $35^{\circ} \mathrm{C}$ ) and dry and winter is moderate (up to -8). Baft city (latitude $29^{\circ} 17^{\prime} \mathrm{N}$ and longitude $56^{\circ} 36^{\prime} \mathrm{E}$ ) is located in the south of Kerman province, 2270 meters above sea level.

Birjandi breed in South Khoransan province is a cashmere producing goat (Ansari-Renani et al., 2011) with a small body size, short legs, straight back, small face, plain horns and small beard. This breed of goat produces mainly black color cashmere South Khorasan province is a highland region with $<250 \mathrm{~mm}$ rain, Summer is hot (up to $41^{\circ} \mathrm{C}$ ) and dry and winter is cold (as low as $-28^{\circ} \mathrm{C}$ ). Goats are most frequently mated in late June/July and kidding takes place at the end of November till January; double blade scissors (Docard) is used to shear animals in late April/early May (Table 1).

Nomad livestock production system is based on mixed herds with $79 \%$ of heads being goats, $10 \%$ sheep and $11 \%$ horses, mules, donkeys, and sometimes camels used for transportation (Ansari-Renani, under publication). Nomads prefer goats over sheep because goats have a higher survival rate during droughts, reproduce faster than other livestock species and their meat is readily marketable. A typical nomad family would run some 250 goats, of which adult female goats (does) constitute $44 \%$; bucks, castrated adult males, male and female yearlings, and male and female kids represent $8 \%, 5 \%, 7 \%$, $12 \%, 10 \%$, and $14 \%$ of the herd population, respectively. The nomads are completely dependent on livestock as a source of income and they have a substantial share in supplying the society with different livestock products. Major product of female and male goats is cashmere which constitutes about $25 \%$ and $33 \%$ of sources of in-

Table 1. Main features of goat management in Iran

\begin{tabular}{|c|c|c|c|c|c|c|c|c|c|c|c|c|}
\hline & \multicolumn{3}{|c|}{ Winter } & \multicolumn{3}{|c|}{ Spring } & \multicolumn{3}{|c|}{ Summer } & \multicolumn{3}{|c|}{ Autumn } \\
\hline & Jan & Feb & Mar & Apr & May & June & Jul & Aug & Sep & Oct & Nov & Dec \\
\hline Mating 1 & & & & & & $* *$ & ** & & & & & \\
\hline Pregnancy & & & & & & & $* * *$ & $* * *$ & $* * *$ & $* * *$ & $* * *$ & $* * *$ \\
\hline Kidding & $* * *$ & & & & & & & & & & $* *$ & $* * *$ \\
\hline Lactating & $* * *$ & $* * *$ & $* * *$ & $* * *$ & $* * *$ & & & & & & & $* * *$ \\
\hline Shearing & & & & $* * *$ & $* * *$ & & & & $* *$ & & & \\
\hline Grazing & $*$ & $* *$ & $* * *$ & $* * *$ & $* * *$ & $* * *$ & $* * *$ & $* * *$ & $* * *$ & $* * *$ & $*$ & $*$ \\
\hline Stubble feeding & $* * *$ & $* * *$ & & & & & & & & & $* * *$ & $* * *$ \\
\hline Concentrate feeding & $*$ & $*$ & & & & & $* *$ & & & & $* *$ & $* *$ \\
\hline
\end{tabular}

Note: *- Less frequent; ${ }^{* *}$ - Middle frequent; ${ }^{* *}$ - Most frequent; 1 - Bucks and does run together year round 
come, respectively (Ansari-Renani, under publication). The goats are also kept for religious and ceremonial purposes, as well as assets and insurance.

\section{Selection of Animals}

A total of 168 goats (75 males and 93 females) of Raeini, Birjandi, and Nadoushan breeds respectively from Kerman, South Khorasan, and Yazd provinces were used in this study. The goats grazed all year but their diets were supplemented during winter with limited amount of forage and grain (containing $15 \mathrm{~g} \mathrm{~N} \mathrm{~kg}^{-1}$ dry matter and 9.1 MJ).

Samples of cashmere were collected randomly from all goats of each sex (females, males) by age (1, 2, 3, and 4 yr) combinations. Sampling was conducted in early spring (mid-April 2009), prior to the seasonal moult and regular annual shearing period. Therefore, fiber growth was about 12 mo and the environmental conditions during the fiber growth period were stated as normal.

In order to facilitate sampling, goats were restrained in a lateral position and about $10 \mathrm{~g}$ of fiber containing both guard hair and cashmere from the left mid-side site was cut from a $4.0 \times 4.0 \mathrm{~cm}$ square close to the skin using regular scissors.

The raw cashmere samples consisting of undercoat and guard hair were sent to the Animal Science Research Institute Fiber Laboratory in Karaj, Iran for analyses. In the Laboratory about a quarter of each sample was weighed with a digital scale and then manually dehaired (separating fiber types: hair and cashmere). The dehaired cashmere, hair fibre, and contaminants were weighed separately in order to calculate the percentage of cashmere yield of the sample. The mean fibre diameter of the washed cashmere samples was measured using a projection microscope. The average staple length for each cashmere sample (in triplicates) was measured to the nearest $0.1 \mathrm{~cm}$.

\section{Statistical Analysis}

Analysis of variance was performed using a general linear model (GLM) of SAS package (SAS, 2008). Differences between means were tested using Duncan's new multiple range test. The statistical model used for cashmere goats of different age, sex and breed was:

$$
Y_{i j k}=\mu+\alpha_{i}+S_{j}+B_{k}+\varepsilon_{i j k}
$$

where: $Y_{i j k}$ : dependent variables; $\mu$ : the overall mean; $\alpha_{i}$ : the effect of age $(\mathrm{i}=1,2,3,4)$; $S_{i}$ : the effect of $\operatorname{sex}(\mathrm{j}=1,2)$; $B_{k}$ : the effect of breed $(\mathrm{k}=1,2,3,4,5), \varepsilon_{i j k}$ : residual error.

All values were expressed as least square means \pm SEM with $\mathrm{P}<0.05$ was considered to be statistically significant.

\section{RESULTS AND DISCUSSION}

Table 2 shows the overall means, standard deviations and ranges for the cashmere traits of all breeds of goats. Cashmere yield (CY) of $51.4 \%$, cashmere fiber diameter (MFD) of $18.7 \mu \mathrm{m}$, staple length (SL) of 42.8 $\mathrm{mm}$ and coefficient of variation of fiber diameter (CVFD) was $19.1 \%$. Breed effect was statistically significant for all traits of cashmere. A large breed effect had also been detected in other cashmere goats (McGregor \& Butler, 2008a and 2008b; McGregor et al., 2009; McGregor et al., 2011).

\section{Mean Fiber Diameter}

Cashmere MFD averaged 17.0-19.5 $\mu \mathrm{m}$ between breeds (Table 2) with an individual range of 15.5-24.5 $\mu \mathrm{m}$ (Table 3). The relationship between MFD and other fleece characteristics are shown in Table 4. Raeini goats with MFD of $19.5 \mu \mathrm{m}$ had the coarsest fiber, and Nadushan goats with $17.0 \mu \mathrm{m}$ had the finest cashmere. Cashmere from one year old goats was significantly finer than cashmere from older goats (about $0.9 \mu \mathrm{m}$, $\mathrm{P}<0.0001$ ), but males tend to increase fiber diameter whereas females tend to decrease it (Table 2). The overall CVFD was $19.1 \%$ (Table 2). Females and four year old goats had smaller CVFD (Table 2).

Results indicate that overall cashmere diameter was $18.7 \pm 0.2 \mu \mathrm{m}$. In a FAO publication Iranian cashmere was described as having a range of diameter of 17-21 $\mu \mathrm{m}$ and that it is chiefly used for weaving (Petrie, 1995). Of all cashmere samples 28 and $21 \%$ had a fiber diameter between 14.90-17.50 and 17.51-18.50 $\mu \mathrm{m}$ respectively (Table 5) similar to low premium Chinese and Mongolian cashmere which is suitable for knitwear. A further $51 \%$ of the cashmere was coarser than $18.50 \mu \mathrm{m}$ (Table 5). A study of McGregor et al. (2009) indicated that $42 \%$ of cashmere samples tested from Osh and Naryn provinces of Kyrgyzstan had a fibre diameter of 16.0 to $18.0 \mu \mathrm{m}$ suitable for either knitwear or weaving. A further $30 \%$ and $21 \%$ of the goat cashmere was between 18.51 to 20.0 and greater than $20.0 \mu \mathrm{m}$, respectively. Similarly in a study with goats in Murghab and Shugnan districts of

Table 2. Means and standard deviations (s.d.) of staple length (SL), mean fiber diameter (MFD), coefficient variation of fiber diameter (CVFD), and cashmere yield (CY) in different cashmere goat breed categories

\begin{tabular}{|c|c|c|c|c|c|}
\hline & No & $\begin{array}{c}\mathrm{SL} \\
(\mathrm{mm})\end{array}$ & $\begin{array}{l}\text { MFD } \\
(\mu \mathrm{m})\end{array}$ & $\begin{array}{c}\text { CVFD } \\
(\%)\end{array}$ & $\begin{array}{l}\text { CY } \\
(\%)\end{array}$ \\
\hline Mean & & $42.8 \pm 1.6$ & $18.7 \pm 0.2$ & $19.1 \pm 0.3$ & $51.4 \pm 1.5$ \\
\hline Sex & & * & $*$ & NS & NS \\
\hline Male & 75 & $45.6 \pm 1.6^{\mathrm{a}}$ & $19.3 \pm 0.2^{\mathrm{a}}$ & $19.5 \pm 0.4$ & $51.0 \pm 1.3$ \\
\hline Female & 93 & $40.5 \pm 1.5^{\mathrm{b}}$ & $18.2 \pm 0.1^{b}$ & $18.7 \pm 0.5$ & $51.8 \pm 1.3$ \\
\hline Age group & & * & $* *$ & ** & $* *$ \\
\hline 1 & 40 & $47.7 \pm 2.1^{\mathrm{a}}$ & $18.1 \pm 0.2^{\mathrm{b}}$ & $19.7 \pm 0.7^{a}$ & $50.6 \pm 1.7^{\mathrm{b}}$ \\
\hline 2 & 37 & $45.1 \pm 2.6^{\mathrm{ab}}$ & $18.8 \pm 0.3^{\mathrm{ab}}$ & $20.0 \pm 0.8^{\mathrm{a}}$ & $56.9 \pm 2.0^{\mathrm{a}}$ \\
\hline 3 & 51 & $41.4 \pm 1.9^{\mathrm{b}}$ & $18.7 \pm 0.3^{\mathrm{ab}}$ & $18.9 \pm 0.5^{\mathrm{ab}}$ & $48.9 \pm 1.8^{\mathrm{b}}$ \\
\hline 4 & 40 & $37.3 \pm 1.9^{c}$ & $19.0 \pm 0.2^{\mathrm{a}}$ & $17.9 \pm 0.5^{\mathrm{b}}$ & $50.3 \pm 1.7^{\mathrm{b}}$ \\
\hline Breed & & * & * & * & ** \\
\hline Raeini & 68 & $55.2 \pm 0.8^{\mathrm{a}}$ & $19.5 \pm 0.2^{\mathrm{a}}$ & $22.6 \pm 0.4^{\mathrm{a}}$ & $53.2 \pm 1.3^{\mathrm{a}}$ \\
\hline Nadoushan & 40 & $30.4 \pm 1.1^{c}$ & $17.0 \pm 0.1^{\mathrm{c}}$ & $15.3 \pm 0.3^{c}$ & $55.8 \pm 2.0^{\mathrm{a}}$ \\
\hline Birjandi & 60 & $36.9 \pm 1.6^{\mathrm{b}}$ & $18.8 \pm 0.2^{\mathrm{b}}$ & $17.6 \pm 0.3^{\mathrm{b}}$ & $46.5 \pm 1.3^{b}$ \\
\hline
\end{tabular}


Table 3. Ranges of staple length (SL), mean fiber diameter (MFD), coefficient variation of fiber diameter (CVFD), and cashmere yield (CY) in different cashmere goat breed categories

\begin{tabular}{|c|c|c|c|c|c|c|}
\hline & & & SL & MFD & CVFD & CY \\
\hline \multirow[t]{4}{*}{ Sex } & Male & Min & 20.3 & 15.9 & 12.4 & 17.2 \\
\hline & & Max & 70.5 & 24.5 & 27.0 & 79.0 \\
\hline & Female & Min & 20.2 & 15.5 & 11.9 & 25.6 \\
\hline & & Max & 67.0 & 22.3 & 32.1 & 80.0 \\
\hline \multirow{8}{*}{$\begin{array}{l}\text { Age } \\
\text { group }\end{array}$} & 1 & Min & 20.3 & 15.5 & 11.9 & 17.2 \\
\hline & & Max & 70.5 & 20.8 & 27.0 & 71.0 \\
\hline & 2 & Min & 20.2 & 15.7 & 12.7 & 35.0 \\
\hline & & Max & 67.0 & 24.2 & 32.1 & 79.0 \\
\hline & 3 & Min & 20.3 & 15.8 & 12.7 & 24.5 \\
\hline & & Max & 70.0 & 24.5 & 28.9 & 80.0 \\
\hline & 4 & Min & 20.2 & 16.4 & 12.4 & 34.5 \\
\hline & & Max & 70.0 & 22.3 & 25.1 & 78.8 \\
\hline \multirow[t]{6}{*}{ Breed } & Raeini & Min & 40.0 & 15.7 & 15.2 & 31.4 \\
\hline & & Max & 70.0 & 24.2 & 32.1 & 79.0 \\
\hline & Nadoushan & Min & 20.2 & 15.5 & 11.9 & 25.6 \\
\hline & & Max & 50.0 & 19.2 & 21.6 & 79.7 \\
\hline & Birjandi & Min & 20.2 & 15.5 & 12.4 & 17.2 \\
\hline & & Max & 70.5 & 24.5 & 23.9 & 68.0 \\
\hline
\end{tabular}

Table 4. Pearson correlation coefficients between staple length (SL), mean fiber diameter (MFD), coefficient variation of fiber diameter (CVFD), and cashmere yield (CY)

\begin{tabular}{ccccc}
\hline & SL & MFD & CVFD & CY \\
\hline SL & 1 & & & \\
MFD & $0.36^{*}$ & 1 & & \\
CVFD & $0.53^{*}$ & $0.27^{*}$ & 1 & \\
CY & -0.03 & -0.05 & 0.11 & 1 \\
\hline
\end{tabular}

Note: * Significantly different from $0(\mathrm{P}<0.001)$.

Pamir region of Tajikistan, it was indicated that $57 \%$ of cashmere samples had a fibre diameter of 14.6 to $21 \mu \mathrm{m}$ (McGregor et al., 2011).

Our finding that older goats had coarser cashmere than yearling goats coincides with McGregor et al. (2009) who also reported that younger goats of different regions of Osh and Naryn provinces of Kyrgyzstan and of Pamir mountain districts of Tajikistan had significantly lower MFD than older goats. The impact of age could be associated with larger body size and reduced skin follicle density and competition for nutrients enabling the follicles to increase in size and therefore fibre diameter of older goats increases.

It was observed that all cashmere goat breeds started a sequential, bilaterally symmetric pattern of shedding in the early spring commencing on the neck, chest and shoulders spreading to the back and rump. In terms of harvesting maximum weight of cashmere, the
Table 5. Proportion (\%) of sampled cashmere within defined quality classes of mean fibre diameter (MFD), cashmere yield (CY) and staple length (SL)

\begin{tabular}{lcccccc}
\hline & MFD & $\%$ & CY & $\%$ & SL & $\%$ \\
\hline All breeds & $14.9-17.5$ & 28 & $<50$ & 47 & $<40$ & 51 \\
& $17.51-18.5$ & 21 & $50-60$ & 33 & $40-50$ & 20 \\
& $18.51-20$ & 30 & $61-70$ & 13 & $50<$ & 29 \\
Raeini & $20<$ & 21 & $70<$ & 7 & & \\
& $14.9-17.5$ & 13 & $<50$ & 41 & $<40$ & 0 \\
& $17.51-18.5$ & 16 & $50-60$ & 38 & $40-50$ & 37 \\
& $18.51-20$ & 19 & $61-70$ & 13 & $50<$ & 63 \\
Nadoushan & $20<$ & 52 & $70<$ & 8 & & \\
& $14.9-17.5$ & 32 & $<50$ & 33 & $<40$ & 80 \\
& $17.51-18.5$ & 16 & $50-60$ & 31 & $40-50$ & 20 \\
& $18.51-20$ & 40 & $61-70$ & 21 & $50<$ & 0 \\
& $20<$ & 12 & $70<$ & 15 & & \\
& $14.9-17.5$ & 20 & $<50$ & 62 & $<40$ & 51 \\
& $17.51-18.5$ & 28 & $50-60$ & 28 & $40-50$ & 39 \\
& $18.51-20$ & 49 & $61-70$ & 10 & $50<$ & 10 \\
& $20<$ & 3 & $70<$ & 0 & & \\
\hline \multirow{4}{*}{ Birjandi } & & & & & &
\end{tabular}

optimal time for a single shearing of cashmere goats would be at the end of winter season before follicle inactivity substantially starts or before onset of shedding. At this stage goats are in their poorest body conditions for the cold weather and very limited feed availability. It is important from the point of the welfare of the goats that some hair is left on the animal after cashmere harvesting as this hair provides an essential protective layer against adverse weather conditions. Use of either machine or hand shearing which removes the entire fleece pose a serious threat and is inconceivable under such conditions. In addition, the presence of unshed long hair and cashmere in the fleece help cashmere fibre loss once cashmere shedding has begun by acting as a physical barrier restraining the cashmere in its position. This allows owners to time cashmere harvesting either using combs or by collecting the clumps of cashmere retained in the fleece. Use of combs reduces further cashmere loss during the shedding season. Unshed cashmere could be sheared in mid-spring when adverse weather conditions are over.

\section{Staple Length}

Average cashmere SL was $42.8 \mathrm{~mm}$ with an average range of 30.4-55.2 mm between breeds (Table 2) with an individual range of $20.2-70.5 \mathrm{~mm}$ (Table 3 ). The relationship between SL and other fleece characteristics are shown in Table 4. Raeini goats with SL of $55.2 \mathrm{~mm}$ had longest, and Nadushan goats with $30.4 \mathrm{~mm}$ had shortest length. Cashmere from one year old goats was significantly longer than cashmere from older goats (about $10.4 \mathrm{~mm}, \mathrm{P}<0.0001$ ), and males also had longer cashmere than females (about $5.0 \mathrm{~mm}, \mathrm{P}<0.0001$ ) (Table 2). In another study with cashmere goats of different Tajikistan 
districts, McGregore et al. (2011) found significant effect on cashmere staple length. Increasing age of goat from 2 to 6 to 8 yr of age was associated with reduced staple length of $11 \mathrm{~mm}$. In the same study they indicated that there was a significant effect of gender on cashmere staple length. Both male and female goats grew cashmere 5-6 $\mathrm{mm}$ shorter than that grown by castrates $(\mathrm{P}<0.0001)$.

Of all samples SL of $38 \%$ was between 40 and 50 $\mathrm{mm}, 51 \%$ shorter than $40 \mathrm{~mm}$ and $29 \%$ longer than 50 $\mathrm{mm}$ (Table 5). As cashmere longer than 34-36 $\mathrm{mm}$ are used for worsted spinning (World Textile Publications, 2010), the results indicate that majority of cashmere of goats would qualify for worsted and semi-worsted industry.

\section{CONCLUSION}

Cashmere of Iranian goat breeds can be characterized as being long however steps must be taken to improve the fineness fiber diameter to capture higher prices in the international markets. Significant differences were found between goats and between breeds indicating the potential to improve cashmere quality and the need for adopting proper management and selection methods, through selection of goats with finer cashmere taking care of maintaining the excellent cashmere staple length and curvature.

\section{REFERENCES}

Ansari-Renani, H. R., P. I. Hynd, \& A. Aghajanzadeh. 2007. Fleece phenotype influences susceptibility to cortisol-induced follicle shutdown in Merino sheep. Asian-Autralas. J. Anim. Sci. 20: 1761-1769. http://dx.doi.org/10.1016/j.sma llrumres.2010.09.013

Ansari-Renani, H. R., Z. Ebadi, S. Moradi, H. R. Baghershah, M. Y. Ansari-Renani, \& S. H. Ameli. 2011. Determination of hair follicle characteristics, density and activity of Iranian cashmere goat breeds. Small Rumin. Res. 95: 128-132.

FAO. 2011. http://faostat.fao.org

McGregor, B. A., C. Kerven, \& S. Toigonbaev. 2011. Sources of variation affecting cashmere grown in the Pamir mountain districts of Tajikistan and implications for industry development. Small Rumin. Res. 99: 7-15. http://dx.doi. org/10.1016/j.smallrumres.2011.01.018

McGregor, B. A., C. Kerven, \& S. Toigonbaev. 2009. Sources of variation contributing to production and quality attributes of Kyrgyz cashmere in Osh and Naryn provinces; Implications for industry development. Small Rumin. Res. 84: 8999. http://dx.doi.org/10.1016/j.smallrumres.2009.06.008

McGregor, B. A. \& K. L. Butler. 2008a. The effects of cashmere attributes on the efficiency of dehairing and dehaired cashmere length. Text. Res. J. 78: 486-496. http://dx.doi.org/10.1 177/0040517507087679

McGregor, B. A. \& K. L. Butler. 2008b. Determinants of cashmere production: the contribution of fleece measurements and animal growth on farms. Small Rumin. Res. 78: 95-105. http://dx.doi.org/10.1016/j.smallrumres.2008.05.007

McGregor, B. A. 2007. Cashmere fiber crimp, crimp form and fiber curvature. International Journal of Sheep and Wool Science 55: 106-129.

Ministry of Agriculture, 2004. The role of livestock and poultry production on national economy.

Nixon, A. J., M. P. Gurnsey, K. Betteridge, R. J. Mitchell, \& R. A. S. Welch. 1991. Seasonal hair follicle activity and fibre growth in some New Zealand cashmere-bearing goats (Capra hircus). J. Zool. (Lond.) 224: 589-598. http://dx.doi. org/10.1111/j.1469-7998.1991.tb03787.x

Petrie, O. J. 1995. Harvesting of textile animal fibres. Fao Agricultural Services Bulletin No. 122. Food and Agricultural Organization of the United Nations, Rome.

SAS. 2008. Version 9.2, SAS Institute Inc. Cary. NC.

Schneider, G. S. 2011. Market indicators. http://www.gschneider.com/indicators/index.php

World Textile Publications. 2010. Specialty fibres. Wool Record Weekly Market Report, February $4^{\text {th }}$. World Textile Publications Ltd., Bradford, UK. 